H. REN, ${ }^{1}$ S.Q. LIU, ${ }^{1}$ X. ZHANG, ${ }^{1}$ AND YA. ZENG ${ }^{2}$

\title{
SPIKE TIMING-DEPENDENT PLASTICITY IN CA1 PYRAMIDAL NEURON- CONTROLLING HIPPOCAMPAL CIRCUITS: A MODEL STUDY
}

\begin{abstract}
Received 21.09.13
Spike timing-dependent plasticity (STDP) plays an important role in sculpting neural circuits to store information in the hippocampus, since motor learning and memory are thought to be closely linked with this type of synaptic plasticity. We built a computational model to study the potential learning rule by linearly changing the synaptic weight and number of the synapses involved. The main findings are the following: (i) changes in the synaptic weight and number of synapses can lead to different long-term changes in the synaptic efficacy; (ii) the first spike pair of two neurons exerts a great influence on the subsequent spike pair; a pre-post spiking pair reinforces the subsequent paired spiking, while a post-pre spiking pair depresses this paired spiking; (iii) when the synaptic weight and synaptic number change, the interval in the first spiking pair is reduced, which directly influences the first spiking pair, and (iv) when a stellate neuron is stimulated weakly or the capacitance of a CA1 pyramidal neuron is decreased, LTP is produced more easily than LTD; in the opposite case, LTD is produced more readily; an increase of the synaptic number can promote activation of CA1 pyramidal neurons.
\end{abstract}

KEYWORDS: computational model, hippocampus, spike timing-dependent plasticity (STDP), synaptic weight and number.

\section{INTRODUCTION}

Since an observation of persistent enhancement of the intensity of synaptic transmission in the hippocampus induced by tetanic stimulation [1], i.e., a phenomenon now generally called long-term potentiation (LTP), studies of activity-dependent synaptic plasticity have become one of the scientific frontier and hot topics in neurobiology [2,3]. Later studies have further addressed the importance of the temporal order of presynaptic and postsynaptic spiking for long-term modifications (LTP and long-term depression, LTD) of a variety of glutamatergic synapses and have defined the "critical windows" for spike timing. When presynaptic spiking precedes postsynaptic spiking (hereafter referred to as "pre-post" within a window of several tens of milliseconds, LTP is induced, whereas spiking of the reverse order ("post-pre") leads to LTD. This form of activity-dependent LTP/LTD is now referred to as spike timing-dependent plasticity

\footnotetext{
1 South China University of Technology, Department of Mathematics, Guangzhou, China.

${ }^{2}$ Beijing University of Technology, Biomedical Engineering Center, Beijing, China.

Correspondence should be addressed to Sh. Liu or Ya. Zeng

(e-mail: yjzeng@bipu.edu.cn).
}

(STDP) [4].

Levy and Steward have examined the effect of relative millisecond-level timing of presynaptic and postsynaptic action potentials (APs) on the plasticity [5]. A later work, by Bi and Poo [6], underscored the importance of precise spike timing, synaptic strength, and postsynaptic cell type in the activity-induced modification of central synapses and suggested that the Hebb's rule may need to be incorporated in a quantitative consideration of spike timing taking into account narrow and asymmetric windows for the induction of synaptic modification. Recently, Works [7] continued to study STDP in in vivo systems to reveal several layers of complexity in STDP. According to a mathematical fitting method of exponential function by Bi and Poo [6], Vassilis et al. [8] built a computational model aimed at investigation of biophysical mechanisms by which storage and recall of spatio-temporal input patterns are achieved in the CA1 microcircuitry.

On the base of a real connection system between different cells in the hippocampus circuit and using computational approaches, we studied the interaction of different inputs, as well as the STDP learning regularities and effects of changes in the parameters of synaptic action, on this phenomenon. In addition, some 
meticulous potentiation and depression phenomena can be simultaneously observed.

\section{METHODS}

Taking into consideration results of the anatomical experiments, the connection system between cells, and physiological parameters of each cell, we tried to construct a computational hippocampus network maximally similar to the real system where all three kinds of the neurons of the rat hippocampus were presented. These were a CA1 pyramidal neuron, a stellate neuron, and a $C A 3$ pyramidal neuron. In order to better simulate real properties of this circuit, we have used only three typical neurons to build the circuit, where perforant-path fibers project to the hippocampus from the entorhinal cortex and form excitatory synapses with the apical dendrite of the CA1 pyramidal neuron, while the CA3 pyramidal neuron is connected with the CA1 pyramidal neuron; the latter also forms excitatory synapses through a set of the fibers called Schaffer collaterals [9] (Fig. 1).

According to the results of natural experiments, the configuration of the hippocampus circuit is easy to be understood, and the sequence of events in this system is also very specific. The physiological parameters for this model related to each neuron were described in detail in the preceding papers $[9,10]$ and in the Appendix. This allowed us to construct our model hippocampus circuit rather similar to the real system.

According to theoretical analysis, a single cell can be characterized as composed by a conduction model and a compartment model. Different parts of the neuron can be described by different compartment numbers. The basic theory of electrical signal transmission is the Rall's cable model; its discrete format corresponds to a neuronal compartment model [11-14]. We should notice that different cell compartments possess different ion channels and some initial ion variables. In general, the parameters and neuronal equations can be presented as follows:

$$
\left\{\begin{array}{l}
C \frac{d V}{d t}=I_{\text {ion }}+I(t)+I_{\text {compartment }}+I_{\text {syn }} \\
\frac{d x}{d t}=\left(x_{\infty}-x\right) / \tau_{x}
\end{array}\right.
$$

In these equations, $C, x=x(V) ; I_{\text {compartment }}$ and $I_{\text {syn }}$ separately indicate the cell membrane capacitance, open or closed channels, external stimulus, compartment currents, and synaptic currents. The properties of chemical synapses were used to describe the connections between the presented cells, and these special connections can be described by the respective excitatory or inhibitory actions [14].

The constructed network was realized within the NEURON environment, and we used MATLAB software to process the data. The simulated results have been repeatedly verified.

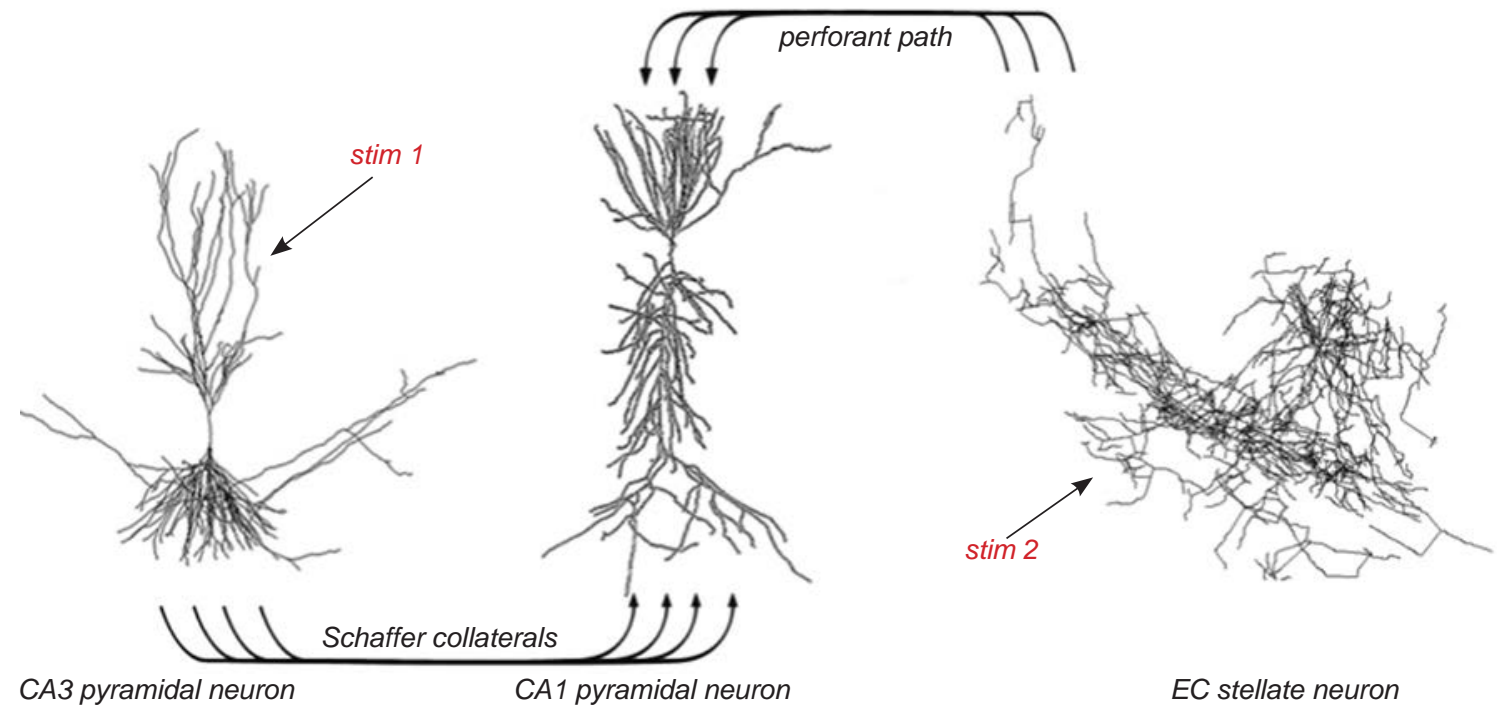

F i g. 1. Scheme of the modeled hippocampal circuit. A CA3 pyramidal neuron, a CA1 pyramidal neuron, an EC stellate neuron, interconnecting fibers, and sites of stimulation are shown.

Р и с. 1. Схема модельованої гіпокампальної нейронної мережі. 


\section{RESULTS}

The synaptic plasticity is ability of the synaptic connection between two neurons to change its efficacy in response to either use or disuse of the transmission over synaptic pathways [15]. Here we simulated the two situations:

1) The synaptic conductance of NMDA receptors is the product of 0.035 and synaptic weight, while the synaptic conductance of AMPA receptors is the product of 0.001 and synaptic weight. Then, we linearly changed the synaptic weight, which is the same as a linearly change in the synaptic conductance.

2) Linearly change in the number of the synapses.

Here, we give a description of the term "normalized EPSP slope". Under initial conditions, the first spike generated by the postsynaptic neuron is marked as AP0. If we change the prerequisites, the postsynaptic neuron will generate a new first AP marked as V1. Considering this, we can characterize the "normalized EPSP slope" by $\mathrm{k}$.

$$
\mathrm{k}=(\mathrm{V} 1-\mathrm{V} 0) / \mathrm{V} 0 \text {. }
$$

LTP and LTD Produced in the CA1 Pyramidal Neuron by Perforant Path Synapses. Results of the previous research [16] showed that direct sensory information arriving at distal CA1 synapses through the perforant path provide compartmentalized instructive signals assessing the saliency of mnemonic information propagated through the hippocampal circuit to proximal synapses. Here, we mostly analyze the impact of perforant path synapses.

At the beginning, we only stimulated the stellate cell through a constant input, and there was no input from Schaffer collaterals to the CA1 pyramidal neuron. When initially the synapse weight was small, the system always worked in the pre-post firing pattern; the critical window shows that the LTP phenomenon is realized within the time borders shown in the experiment [17]. The first spiking pair interval demonstrated a tendency toward decrease when the synaptic weight increases (Fig. 2A). If we increase the synaptic weight to a certain large value, the system always begins to work corresponding to the post-pre firing pattern, where LTD can develop (C).

When the number of synapse is initially small, the
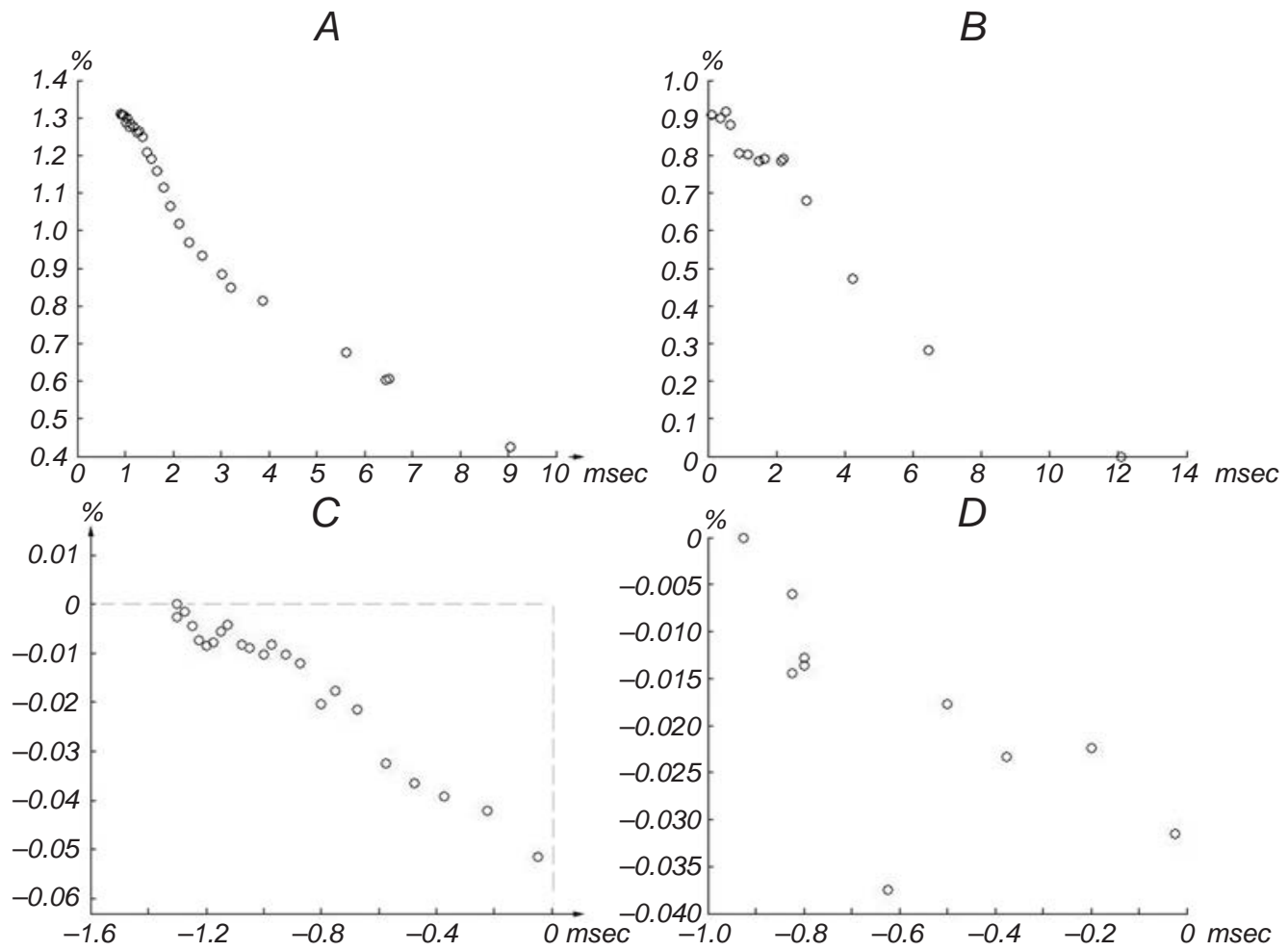

F i g. 2. The critical window. Effects of changes in the perforant-path synaptic number and weight. A) Synaptic number is 60 , synaptic weight varies from 0.08 to 0.35 . B) Synaptic weight is 0.5 , synaptic number varies from 15 to 51 . C) Synaptic number is 60 , synaptic weight varies from 1.45 to 0.4 . D) Synaptic weight is 0.5 , synaptic number varies from 81 to 54 .

Р и с. 2. Вплив кількості синапсів та синаптичної ваги зв’язків перфорантного шляху на критичне вікно. 
system also shows a pre-post firing pattern. If we increase the synaptic number up to 51 (the system in this case works in the pre-post firing mode), the critical window shows that the LTP phenomenon is manifested (Fig. 2B). On the contrast, when the synapse number is decreased to 54 from a larger number, the LTD phenomenon also can be reached (D).

During LTP, the first pair of spikes is interpreted as playing a dominant role in the restriction of subsequent postsynaptic spiking. The first pre-post spiking pair can intensify the subsequent paired spiking; nevertheless, potentiation would recede when the firing interval descends (Fig. 3 A, B). During LTD, however, the inversed conclusion can be reached $(C, D)$.

According to the computational simulation, both changes of the synaptic weight and synaptic number would lead to the replacement of LTP and LTD. But how the two long-term changes provide storing and delivering of information? This question is quite difficult to prove. Moreover, the computational results can inspire us to test and simulate the various factors, which is extremely complicate to be realized in the biological experiments to complete the STDP theory.

LTP Produced in the CA1 Pyramidal Neuron by Schaffer-Collateral Synapses. Clarke and Stephen [18] showed that selective induction of different forms of LTP is achieved via spatial segregation of functionally distinct calcium signals, where activation of NMDA receptors is necessary. So, we studied the impact of the Schaffer-collateral synapses on the CA1 pyramidal neuron to further understand the phenomenon of synaptic plasticity.

Here we also stimulated the CA3 pyramidal neuron via a constant input. In the same way, we still studied the impact of the Schaffer-collateral synaptic weight and synaptic number. We found that only LTP was induced by increases in the synaptic weight and synaptic number (Fig. 4). Both the effect of the first spiking pair and the trend of the spiking interval were similar with the results described in the first paragraph of Results. The difference was that we failed to find the post-pre pattern of the first spiking pair interval,

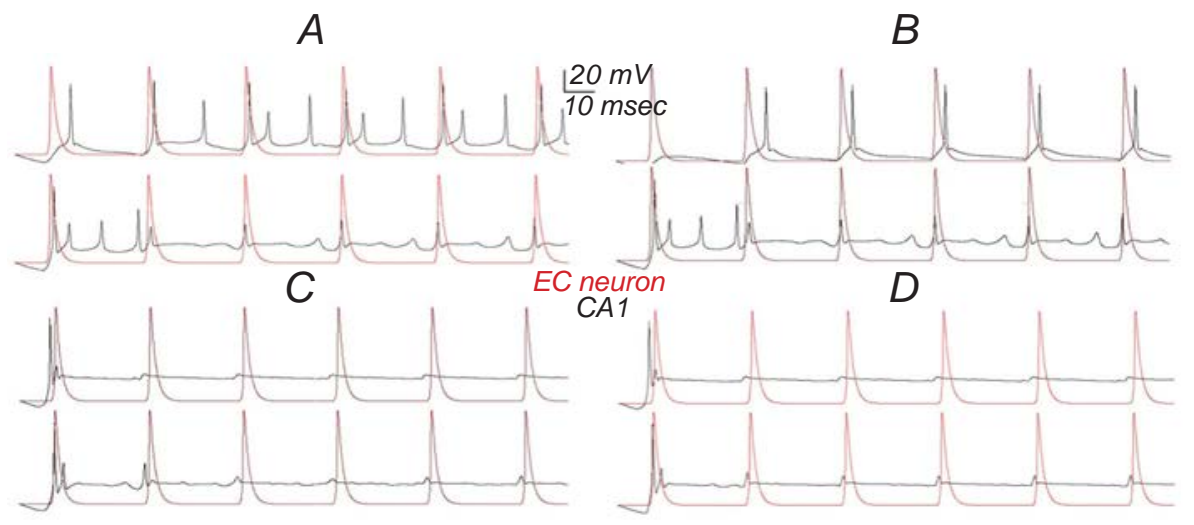

F i g. 3. The first spiking pair restricts subsequent postsynaptic spiking. The perforant- path synaptic weight and number are: A) top 0.2 and 36 , bottom 0.5 and 36 ; B) top 0.5 and 12 , bottom 0.5 and 36 ; C) top 0.7 and 96 , bottom 0.2 and 96 ; D) top 0.8 and 96 , bottom 0.8 and 48 , respectively. Red line shows the firing pattern of the stellate neuron, and black line shows that of the CA1 pyramidal neuron.

P и с. 3. Вплив параметрів синапсів перфорантного шляху, що визначають характеристики першої пари імпульсів, на генерацію другої пари імпульсів.

$A$

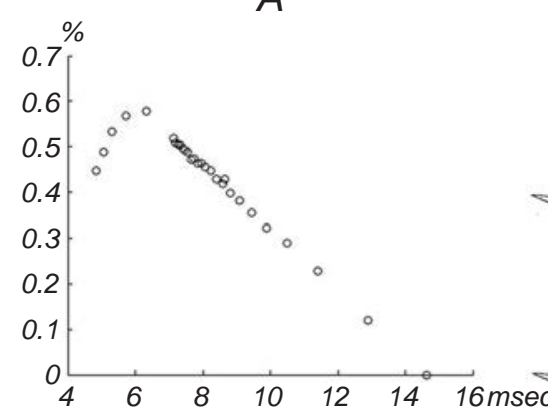

B

F i g. 4. The critical window (A) and changes in the postsynaptic spiking (B) at changes in the parameters of synapses of Schaffer collaterals. A) Synaptic number is 48, and synaptic weight varies from 0.2 to 3.0. B) Restriction of the following postsynaptic spiking by the first spiking pair; blue line shows firing of the CA3 pyramidal neuron, and black line shows that of the CA1 pyramidal neuron. The synaptic weight and number of synapses of Schaffer collaterals are: top, synaptic weight is 0.7 and number of synapses is 54; bottom, the respective parameters are 1.4 and 54 .

Р и с. 4. Вплив кількості синапсів та синаптичної ваги зв'язків колатералей Шафера на критичне вікно. 
which can induce LTD.

From the aforementioned research, we acquired some properties of LTP and LTD; now we will summarize their difference and similarity. The difference mainly is related to the initial state, magnitude, and effect of the first spiking pair interval (detailed description was given in the above paragraph). The similarity is that the magnitude of the effect of the first spiking pair interval demonstrated a decreasing trend in both LTP and LTD. Transformation of the role of the first spiking pair depends on the synaptic weight and number of synapses. The smaller the synaptic weight and number of synapses, the more obvious the inhibitory function. We should, however, notice that the first firing interval also depends on the synaptic weight and number of synapses. We found that when the first spiking pair interval is reduced, the peak voltages in the CA1 pyramidal neuron decrease, and this mode of inhibition depends on firing of the presynaptic stellate neuron. The less pre-bursting spikes, the more obvious

A
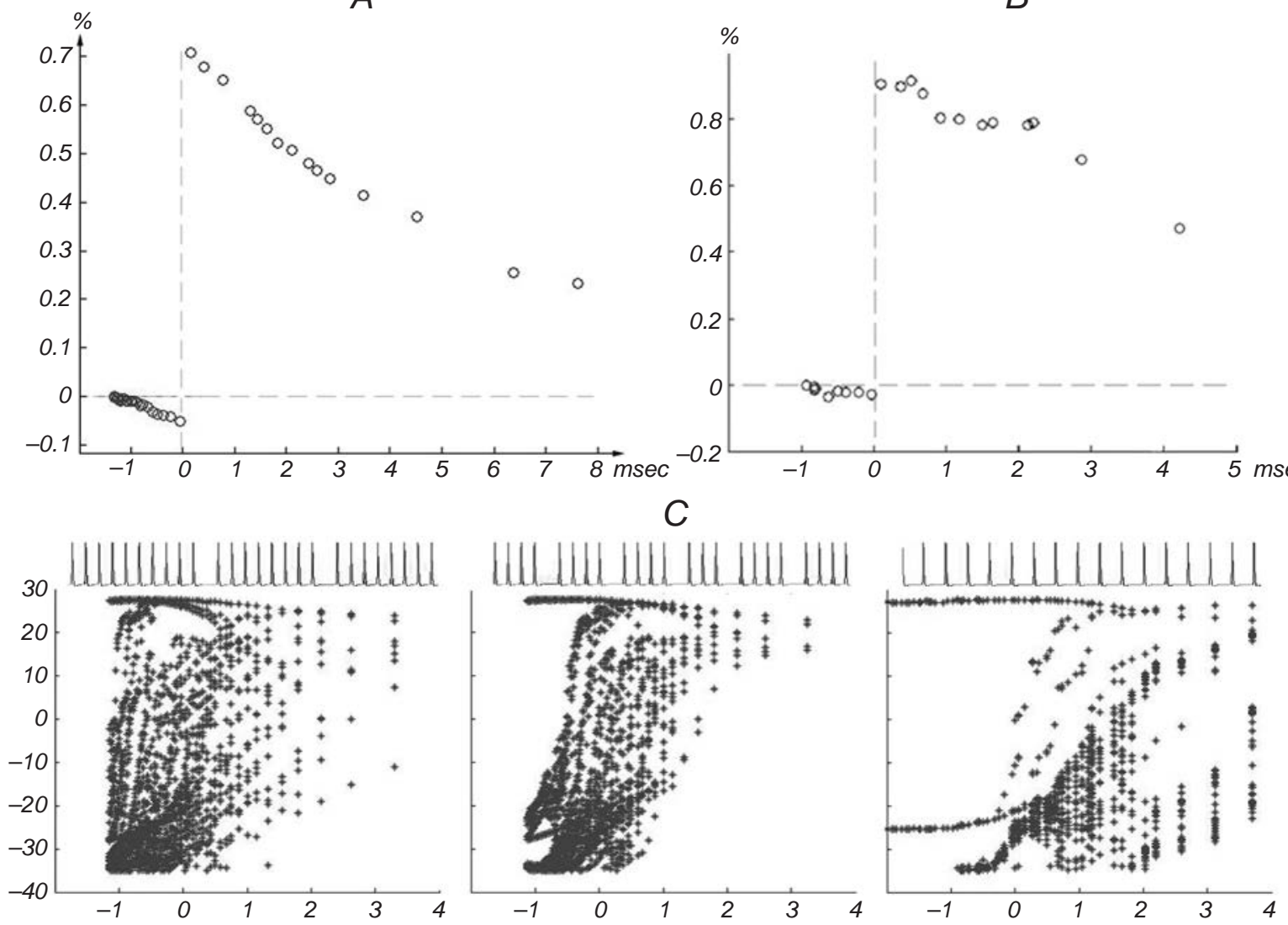

F i g. 5. Comparison of the influences of the first spiking interval on induction of LTD and LTP (A and B) and the relationship between the peak voltage in the CA1 pyramidal neuron and the first spiking interval at different firing patterns of the presynaptic stellate neuron (C).

P и с. 5. Порівняльний вплив інтервалу між імпульсами першої пари на індукцію тривалої депресії або тривалої потенціації $(A, B)$ та залежність зміни потенціалу у пірамідному нейроні від першого інтервалу при різних патернах розряду в зірчастому нейроні (C).

NEUROPHYSIOLOGY / НЕЙРОФИЗИОЛОГИЯ.-2014.-T. 46, № 4 
ces of the CA1 pyramidal neuron or a weaker external stimulus applied to this neuron (Fig. 6).

Function of Schaffer-Collateral Synapses on the CA1 Pyramidal Neuron. Jarsky et al. [19] examined the function of the distal synaptic inputs, and the results led to three predictions that were confirmed in the experiments using rat hippocampal slices. On the basis of the cited research, we primarily studied the function of Schaffer-collateral synapses on the CA1 pyramidal neuron.

Here, the CA1 pyramidal neuron is only connected with the stellate neuron that receives a constant external stimulus. In this case, we can evaluate the relationship between the necessary synaptic number and synaptic weight. To study how the Schaffer-collateral inputs affect this relationship, we connected the CA3 pyramidal neuron with the $C A 1$ pyramidal neuron once again. The necessary synaptic number decreased in both inputs in contrast to the situation without Schaffer-collateral inputs. The Schaffer-collateral input can better promote the efficiency of activation of the CA1 pyramidal neuron (Fig. 7A). Then, we fixed the synaptic weights and could see that activation of the CA1 pyramidal neuron would be promoted by increasing the numbers of two kinds of synapses (B).

Then, we analyzed the influence of Schaffer collaterals on the perforant path by changing the perforant-path synaptic weight, and LTD and LTP were reproduced again. Nevertheless, the range of $\mathrm{k}$ is very small in the case of LTD, and the change of $\mathrm{k}$ is wider in the case of LTP than those without application of the stimulus to Schaffer collaterals (Fig. 8 A, B).

Based on the role of the first spiking pair, we have discussed above, when the first spiking pair has a prepost firing pattern, the subsequent presynapse spiking can promote firing of the postsynapse in the perforantpath synapses. However, such promotion decreases after firing of the CA3 pyramidal neurons even though LTP is expected to be induced in the Schaffercollateral synapses (Fig. 8C).
A $\quad B$
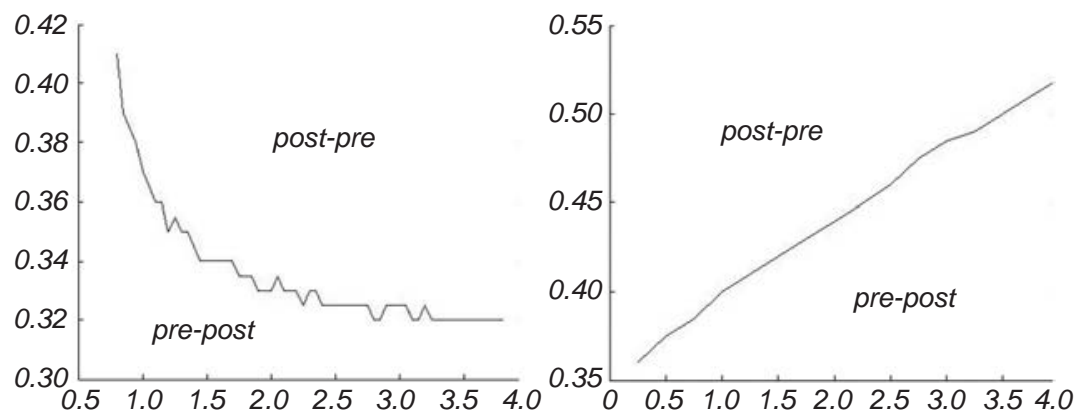

F i g. 6. Relationship between the critical value at two patterns and the intensity of an external stimulus (A) and relationship between the critical value at two patterns and the membrane capacitance of the CA1 pyramidal neuron (B).

Р и с. 6. Взаємозалежність критичного значення при двох патернах імпульсації, інтенсивності зовнішнього стимулу (А) та ємності мембрани пірамідного нейрона $C A 1$ (B).

A
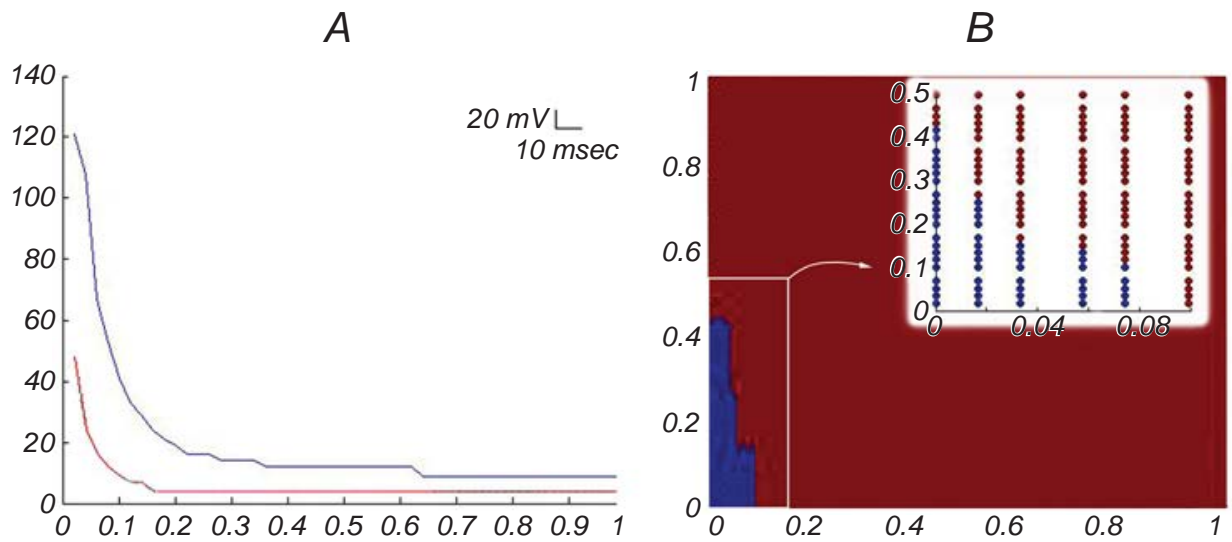

F i g. 7. Relationship between the synaptic weight of perforant-path synapses and necessary synaptic number. Blue line is such relationship at stimulation of only the perforant path; red line is that at stimulation of both the perforant path and Schaffer-collaterals (A). Activation of the CA1 pyramidal neuron is promoted because increases of the numbers of synapses of the above-mentioned types. Blue points show situations where the CA1 pyramidal neuron was not activated, and red points show those where this neuron was successfully excited.

P и с. 7. Залежність між синаптичною вагою зв'язків перфорантного шляху та колатералей Шафера і необхідною кількістю синаптичних контактів, котра визначає активацію пірамідного нейрона зони СA1. 
A

$B$
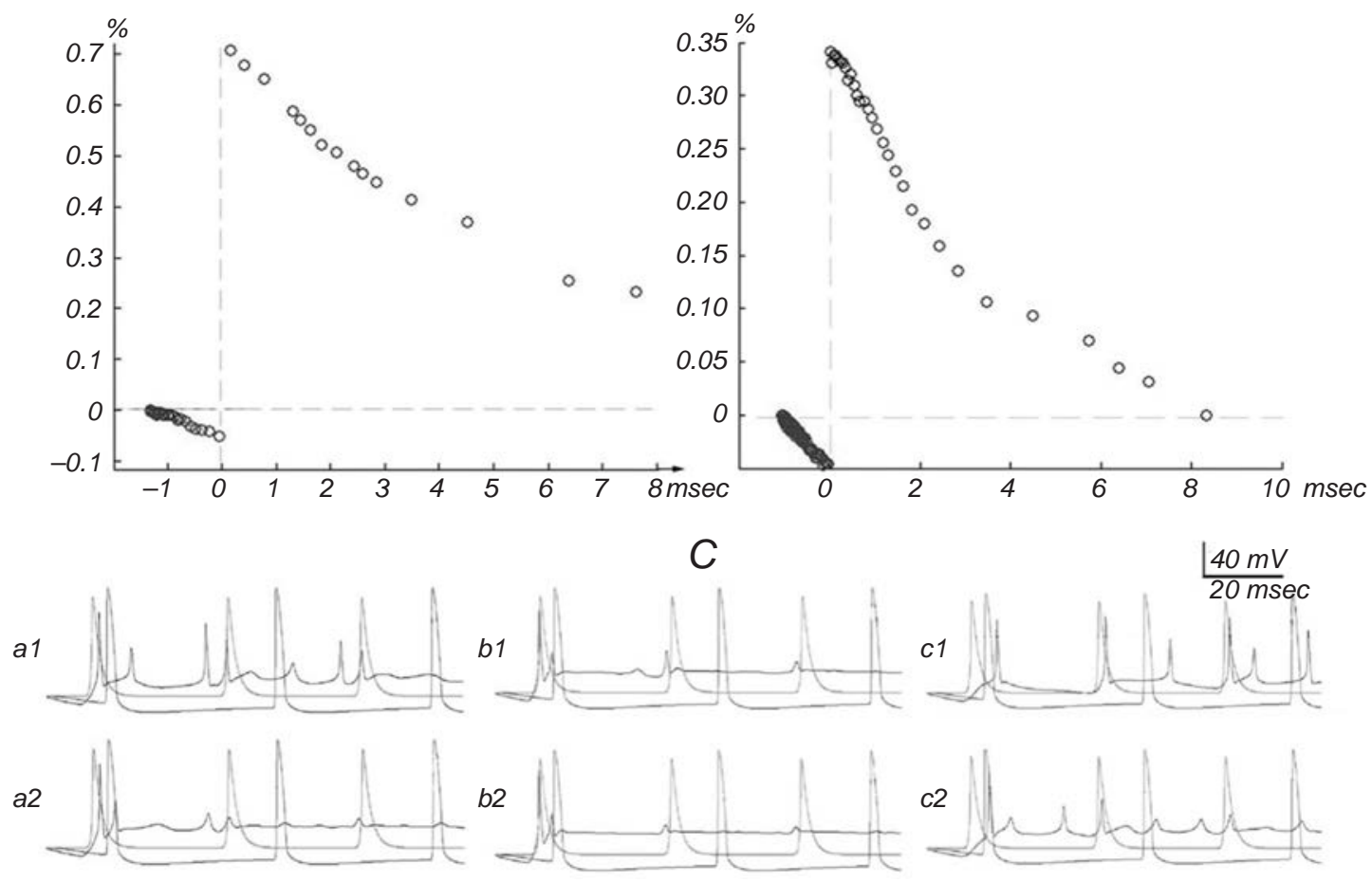

F i g. 8. The same as in Fig. 7, but at stimulation of the perforant path; black and blue dots show the cases of LTP and LTD, respectively (A); effects of combined stimulation of synapses of the perforant path and Schaffer collaterals (B); illustration of the firing patterns of different neurons ( $\mathrm{C}$; blue, red, and black lines are those of the CA3 pyramidal neuron, EC stellate neuron, and CA1 pyramidal neuron, respectively).

Р и с. 8. Залежність індукції тривалої потенціації або тривалої депресії від сили стимуляції перфорантного шляху та колатералей Шафера.

\section{DISCUSSION}

Thus, we tried to study the mechanisms of the hippocampus circuit model using variations of the firing pattern qualities. We mainly studied interaction of the two synapse groups on the CA1 pyramidal neuron and examined the synaptic plasticity. There are several important points to be discussed.

1. Changes in the synaptic weight and synaptic number between the CA1 pyramidal neuron and stellate neuron will lead to long-term changes in the former neuron, namely manifestations of LTD and LTP. The first spike pair generated by the postsynaptic neuron (CA1 pyramidal neuron) plays an important role in modification of the subsequent spike pair. The prepost firing pattern plays a positive role in facilitation of the subsequent spiking. On the contrary, the postpre firing pattern plays a negative role.

2. Changes in the synaptic weight and synaptic number between the CA1 and CA3 pyramidal neurons only lead exclusively to LTP in the CA1 pyramidal neuron. When we change the synaptic weight, the first spiking pair interval will be reduced, which directly inhibit the first spiking pair changes.

3. When we apply a weak external stimulus to the neurons or decrease the capacitance of the CA1 pyramidal neuron, LTP is produced more easily than LTD. In addition, Schaffer collaterals can better promote activation of the CA1 pyramidal neuron; however, they inhibit the potentiation of the first spiking pair.

Based on previous analyses, the constructed hippocampal network has a clear network configuration and mimics a number of functions. In this paper, we mainly discussed the synapse modification due to linear changes in the synaptic number and weight and interaction between the perforant-path inputs and Shaffer-collateral inputs. In fact, some results of our study are very similar to those obtained in realistic experiments. However, it is difficult to formulate general learning rules in biological experiments; thus, model computation results will be helpful with respect to future research. 


\section{Appendix. Supporting information}

Supplementary data associated with this article are presented in the online version at $\mathrm{http}: / /$ neuromorpho.org/ and http://senselab.med.yale.edu/modeldb/

Х. Рен ${ }^{1}, Ш . К^{\prime} ю . ~ Л ь ю 1, ~ К с . ~ Ж а н г ', ~ Я . ~ З е н 2^{2}$

\section{ЗАЛЕЖНА ВІД ЧАСУ ГЕНЕРАЦІЇ ІМПУЛЬСІВ ПЛАСТИЧНІСТЬ У НЕЙРОННИХ МЕРЕЖАХ ГІПОКАМПА, ЩО КОНТРОЛЮЮТЬ АКТИВНІСТЬ ПІРАМІДНИХ НЕЙРОНІВ ЗОНИ СА1: МОДЕЛЬНЕ ДОСЛІДЖЕННЯ}

${ }^{1}$ Південнокитайський технологічний університет, Гуанчжоу (Китай).

\author{
${ }^{2}$ Центр біомедичної інженерії Пекінського технологічного \\ університету (Китай). \\ Р е $з$ ю м е
}

Пластичність, залежна від часу генерації імпульсів (spike timing-dependent plasticity - STDP), відіграє важливу роль у функціонуванні нейронних мереж гіпокампа, що накопичують інформацію; вважають, що моторне навчання та пам'ять тісно пов'язані зі синаптичною пластичністю саме цього типу. Ми створили комп’ютерну модель, щоб вивчити можливі закономірності в процесі навчання, залежні від лінійних змін синаптичної ваги та кількості залучених синапсів у таких мережах. Основні експериментальні знахідки були наступними: 1) варіювання синаптичної ваги та числа синапсів можуть призводити до різних тривалих змін ефективності синаптичної передачі; 2) перша пара імпульсів, генерована двома синаптично пов'язаними нейронами, здійснює потужний вплив на наступну пару імпульсів; пара імпульсів у послідовності “пре-пост" полегшує генерацію наступної пари імпульсів, тоді як пара імпульсів у послідовності "пост-пре" пригнічує таку парну генерацію; 3) коли змінюються синаптична вага та кількість залучених синапсів, міжімпульсний інтервал у першій парі скорочується, тобто реалізується прямий вплив на характеристики такої пари; 4) коли інтенсивність стимуляції зірчастого нейрона $€$ низькою або ємність мембрани пірамідного нейрона зони CA1 $\mathrm{e}$ зменшеною, тривала потенціація синаптичної передачі індукується легше, ніж тривала депресія; в іншому випадку легше виникає тривала депресія; збільшення кількості синапсів сприяє активації пірамідних нейронів у зоні CA1.

\section{REFERENCES}

1. T. V. Bliss and T. Lomo, "Long-lasting potentiation of synaptic transmission in the dentate area of the anaesthetized rabbit following stimulation of the perforant path," J. Physiol., 232,
331-356 (1973).

2. R. C. Malenka and S. A. Siegelbaum, Synaptic Plasticity, Johns Hopkins Univ. Press (2001).

3. S. J. Martin, P. D. Grimwood, and R. G. Morris, "Synaptic plasticity and memory: an evaluation of the hypothesis," Annu. Rev. Neurosci., 23, 649-711 (2000).

4. Y. Dan and M. M. Poo, "Spike timing-dependent plasticity: from synapse to perception," Physiol. Rev., 86, 1033-1048 (2006)

5. W. B. Levy and O. Steward, "Temporal contiguity requirements for long-term associative potentiation/ depression in the hippocampus," Neuroscience, 8, No. 4, 791-797 (1983).

6. G. Q. Bi and M. M. Poo, "Synaptic modifications in cultured hippocampal neurons: Dependence on spike timing, synaptic strength, and postsynaptic cell type," J. Neurosci., 18, No. 24, 10464-10472 (1998).

7. C. Natalia and Y. Dan, "Spike timing-dependent plasticity: A hebbian learning rule," Ann. Rev. Neurosci., 31, 25-46 (2008).

8. C. Vassilis, C. Stuart, and P. G. Bruce, "Encoding and retrieval in a model of the hippocampal CA1 microcircuit," Hippocampus, 20, 423-446 (2010).

9. M. Royeck, M. T. Horstmann, S. Remy, et al., "Role of axonal NaV1.6 sodium channels in action potential initiation of CA1 pyramidal neurons," J. Neurophysiol., 100, No. 4, 2361-2380 (2008).

10. H. Peter, E. Daniel, B. Angela, et al., "Distinct classes of pyramidal cells exhibit mutually exclusive firing patterns in hippocampal area CA3," Hippocampus, 18, No. 4, 411-424 (2008).

11. W. M. Yamada, C. Koch, and P. R. Adams, Multiple Channels and Calcium Dynamics, MIT Press, Cambridge (1987), pp. $97-134$

12. M. Migliore and G. M. Shepherd, "Dendritic action potentials connect distributed dendrodendritic microcircuits," J. Comput. Neurosci., 24, 207-221 (2008).

13. R. Michel, M. T. Horstmann, R. Stefan, et al., "Role of axonal $\mathrm{Na} V 1.6$ sodium channels in action potential initiation of CA1 pyramidal neurons," J. Physiol., 4, 2361-2380 (2008).

14. L. Wang and S. Q. Liu, "Neural circuit and its functional roles in cerebellar cortex," Neurosci. Bull., 27, No. 3, 173-184 (2011).

15. J. R. Hughes, "Post-tetanic potentiation," Physiol. Rev., 38, No. 1, 91-113 (1958).

16. T. D. Joshua, T. David, and A. S. Steven, “A role for synaptic inputs at distal dendrites: Instructive signals for hippocampal long-term plasticity," Neuron, 56, 866-879 (2007).

17. J. Tim, R. Alex, L. K. William, and S. Nelson, "Conditional dendritic spike propagation following distal synaptic activation of hippocampal CA1 pyramidal neurons," Nat. Neurosci., 8, 1667-1676 (2005).

18. R. R. Clarke and J. R. Stephen, "Spatial segregation of neuronal calcium signals encodes different forms of LTP in rat hippocampus," J. Physiol., 570, No. 1, 97-111 (2006).

19. T. Jarsky, A. Roxin, W. L. Kath, and N. Spruston, "Conditional dendritic spike propagation following distal synaptic activation of hippocampal CA1 pyramidal neurons," Nat. Neurosci., 8, No. 12, 1667-1676 (2005). 